\title{
Molecularly imprinted polyacrylonitrile adsorbents for the capture of $\mathrm{Cs}^{+}$ions
}

\author{
Hironao Iwasaki and Masakazu Yoshikawa
}

Polymeric materials can be directly converted into molecular recognition materials by alternative molecular imprinting. To produce adsorbents that specifically adsorb cesium ions, a polymeric adsorbent was converted from polyacrylonitrile, adopting cesium chloride as a print molecule. The adsorption ability of the molecularly imprinted adsorbent was studied by surface plasmon resonance spectroscopy and atomic absorption analysis. The results revealed that $\mathrm{Cs}^{+}$-recognition sites were formed in the presence of $\mathrm{CsCl}$ during the adsorbent preparation process. The affinity constant between $\mathrm{Cs}^{+}$and and $\mathrm{Cs}^{+}$-recognition sites ranged from $4.2 \times 10^{3}$ to $7.1 \times 10^{3} \mathrm{~mol}^{-1} \mathrm{dm}^{3}$. The adsorbents obtained in the present study are expected to be useful for the specific adsorption of $\mathrm{Cs}^{+}$from nuclear waste.

Polymer Journal (2016) 48, 1151-1156; doi:10.1038/pj.2016.87; published online 5 October 2016

\section{INTRODUCTION}

After the Great East Japan Earthquake hit northeast Japan on 11th March 2011, ${ }^{1}$ the reactor units of boiling water reactors were overheated because of the loss of cooling systems. This led to explosions and a release of radioactivity, initially into the air, followed by fatal leakage of contaminated water into the sea. This surrounding water is still contaminated with the released ${ }^{137} \mathrm{Cs}$ and ${ }^{90} \mathrm{Sr}$, which have halflives of 30 and 28.8 years, respectively. Not only membranologists but also molecular imprinters must contribute to solve the ensuing problems.

Thus far, Prussian blue $e^{2-5}$ and zeolites ${ }^{6-11}$ have been intensively studied as cesium adsorbents. In addition to these materials, molecularly imprinted materials can be potentially used as cesium adsorbents. Molecular imprinting is one of the most facile ways to endow polymeric materials with specific recognition sites toward target substrates such as organic materials, ${ }^{12-19}$ metal ions ${ }^{13,18,20}$ and anionic species. ${ }^{21,22}$ Additionally, alternative molecular imprinting is a much more facile way to introduce molecular recognition sites into polymeric materials. ${ }^{23-25}$ Alternative molecular imprinting can be traced back to the pioneering study reported in 1962 by Michaels et al. ${ }^{26}$ In this method, a polymeric material was used as a functional polymer instead of functional and crosslinkable monomers for conventional molecular imprinting, as first proposed by Wulff and Sarhan. ${ }^{27}$

In the present study, the authors aimed to obtain molecularly imprinted adsorbents for the capture of $\mathrm{Cs}^{+}$from aqueous solutions. In studies on molecular imprinting, it is indispensable to confirm the formation of molecular recognition sites in the obtained molecularly imprinted adsorbents (materials). In the present study on $\mathrm{Cs}^{+}$-recognizing adsorbents, dissociative functional moieties were expected to disturb experiments, although dissociative functional groups with anionic charges were expected to enhance the capture of $\mathrm{Cs}^{+}$. Thus, nonionic neutral polyacrylonitrile (PAN), which is expected to form durable materials, was adopted as a candidate polymer to form molecularly imprinted adsorbents, and $\mathrm{Cs}^{+}(\mathrm{CsCl})$ was adopted as a print molecule.

The $\mathrm{Cs}^{+}$-capture performance of the molecularly imprinted PAN adsorbents is described in this article.

\section{EXPERIMENTAL PROCEDURE}

Materials

Acrylonitrile, ${ }^{28} \quad 2,2^{\prime}$-azobis(2-methylpropionitrile), ${ }^{29} \quad$ toluene $^{28} \quad$ and $\mathrm{N}, \mathrm{N}$-dimethylformamide $(\mathrm{DMF})^{28}$ were purified by the usual methods. Methanol, 1,1,1,3,3,3-hexafluoro-2-propanol (HFIP), $\mathrm{CsCl}, \mathrm{NaClO}_{4}$ and $\mathrm{NaCl}$ were used without purification. Water purified with an ultrapure water system (Simpli Lab. Millipore S.A., Molsheim, France) was used.

\section{Preparation of PAN}

A total of $40.17 \mathrm{~g}(0.757 \mathrm{~mol})$ of acrylonitrile, $660.3 \mathrm{mg}\left(4.02 \times 10^{-3} \mathrm{~mol}\right)$ of $2,2^{\prime}$-azobis(2-methylpropionitrile) and $200 \mathrm{~cm}^{3}$ of toluene were placed in an ampoule. The mixture was degassed by three freeze-pump-thaw cycles and sealed off under reduced pressure, which was below $1.3 \times 10^{-2} \mathrm{~Pa}$ $\left(10^{-4} \mathrm{~mm} \mathrm{Hg}\right)$. The sealed ampoule was shaken in a water bath at a constant temperature of $45^{\circ} \mathrm{C}$ for $96 \mathrm{~h}$. The obtained precipitate, PAN, was first washed with toluene, then with methanol and finally dried in vacuo. An amount of $39.44 \mathrm{~g}$ of PAN was obtained.

\section{Construction of $\mathrm{Cs}^{+}$-recognition adsorbents}

The molecularly imprinted films possessing molecular recognition sites for $\mathrm{Cs}^{+}$ were prepared for surface plasmon resonance (SPR) spectroscopy as follows: a gold-deposited glass plate was immersed in a $1.0 \times 10^{-5} \mathrm{~mol} \mathrm{dm}^{-3}$ solution of 1-octanethiol in ethanol for $30 \mathrm{~min}$ at ambient temperature before molecular imprinting. The film was prepared by spin casting a $1.0 \mathrm{~g} \mathrm{dm}^{-3} \mathrm{HFIP}$ solution 
of PAN onto the pre-treated, gold-deposited glass plate. The rotation speed for spin casting was 3000 r.p.m. A prescribed amount of the print molecule $(\mathrm{CsCl})$ was dissolved in the spin-casting solution for the preparation of molecularly imprinted films. The molecularly imprinted adsorbents with molecular imprinting ratios of $0.25,0.50,0.75$ and 1.00 were named Cs-025, Cs-050, Cs- 075 and Cs-100, respectively. The molecular imprinting ratio was defined as the ratio of the mole number of $\mathrm{CsCl}$ print molecules to that of the constitutional repeating unit of PAN. The molecularly imprinted film for $\mathrm{Na}^{+}$was prepared using DMF as the solvent and $\mathrm{NaClO}_{4}$ as the print molecule. The control film was prepared from HFIP solution without a print molecule.

The molecularly imprinted adsorbents for the study of atomic absorption were prepared as follows: $10 \mathrm{~cm}^{3}$ of $20 \mathrm{~g} \mathrm{dm}^{-3}$ HFIP solution of PAN containing $\mathrm{CsCl}$ as a print molecule was poured into a flat laboratory dish of $9.0 \mathrm{~cm}$ diameter and dried at ambient temperature for $24 \mathrm{~h}$, and then additionally at $50{ }^{\circ} \mathrm{C}$ for $24 \mathrm{~h}$. To make the adsorbent for $\mathrm{Na}^{+}$recognition, $10 \mathrm{~cm}^{3}$ of DMF solution $\left(20 \mathrm{~g} \mathrm{dm}^{-3}\right)$ was poured into a flat laboratory dish of $9.0 \mathrm{~cm}$ diameter and dried at $50^{\circ} \mathrm{C}$ for $288 \mathrm{~h}$. The control adsorbent was prepared from a DMF solution without a print molecule.

The print molecule, such as $\mathrm{CsCl}$ and $\mathrm{NaClO}_{4}$, was removed from the molecularly imprinted adsorbents by $\mathrm{H}_{2} \mathrm{O}$ until the print salt was almost undetectable in $\mathrm{H}_{2} \mathrm{O}$ in atomic absorption analysis. The thicknesses of the CsCl-imprinted adsorbent, $\mathrm{NaClO}_{4}$-imprinted adsorbent and the control are summarized in Table 1.

\section{Evaluation of molecular recognition ability of molecularly imprinted adsorbents}

The molecular recognition ability of the prepared films toward $\mathrm{Cs}^{+}$or $\mathrm{Na}^{+}$was evaluated by SPR spectroscopy. Incident light with $670 \mathrm{~nm}$ was chosen. The change in the incident angle $(\Delta \theta)$ as a result of the addition of substrate was recorded on the SPR instrument (SPR670S; Nippon Laser and Electronic Laboratory, Nagoya, Japan). During the measurement, $\mathrm{H}_{2} \mathrm{O}$ was passed over the molecularly imprinted material surface at $5.0 \mathrm{~mm}^{3} \mathrm{~min}^{-1}$. The flow was periodically replaced with the aqueous solution containing $\mathrm{CsCl}$ or $\mathrm{NaCl}$. The experiments were carried out at $27^{\circ} \mathrm{C}$.

The amounts of $\mathrm{CsCl}$ or $\mathrm{NaCl}$ incorporated into the adsorbents were quantitatively determined by conventional adsorption experiments. The adsorbent was immersed in a $1.0 \times 10^{-2} \mathrm{~mol} \mathrm{dm}^{-3}$ aqueous $\mathrm{CsCl}$ or $\mathrm{NaCl}$ solution and equilibrated at $27^{\circ} \mathrm{C}$. After equilibration with the aqueous solution, the adsorbent was removed from the immersing solution. The free solution adhering on the surface was blotted, and the adsorbent was then transferred to $\mathrm{H}_{2} \mathrm{O}$ to desorb $\mathrm{Cs}^{+}$or $\mathrm{Na}^{+}$from it. An aliquot of the aqueous solution from desorption was used for quantitative estimation by atomic absorption (AA-6500 Shimadzu Atomic Absorption Spectrophotometer; Shimadzu, Kyoto, Japan).

\section{RESULTS AND DISCUSSION}

\section{Adsorption of $\mathrm{Cs}^{+}$}

In the present study, adsorption phenomena of molecularly imprinted adsorbents were studied using SPR spectroscopy because SPR spectroscopy provides a rapid and facile evaluation method ${ }^{30-35}$ compared with the adsorption experiments that are usually used for the evaluation of molecularly imprinted materials. ${ }^{36}$ The relationship between the reflected intensity and the angle of incidence gives the minimum reflected intensity, corresponding to the excitation of surface plasmons at the gold-solution interface. The value of the incident angle giving the minimum reflected intensity $(\theta)$ shifts with

Table 1 Thickness of various adsorbents

\begin{tabular}{lccccc}
\hline Adsorbent & Control & Cs-025 & Cs-050 & Cs-075 & Cs-100 \\
Thickness $(\mu \mathrm{m})$ & 41 & 76 & 212 & 205 & 333 \\
\hline Adsorbent & & Na-025 & & \\
Thickness $(\mu \mathrm{m})$ & 71 & & \\
\hline
\end{tabular}

the change in the reflective index of the interfacial region close to the gold surface. ${ }^{37,38}$ The shift in $\theta(\Delta \theta)$ is proportional to the amount of adsorbed substrate at the surface. Using $\Delta \theta$, an apparent adsorption isotherm of a given target molecule can be drawn. In the present study, $\mathrm{Cs}^{+}$was adopted as the print molecule because the present study was carried out with the aim of obtaining adsorbents of $\mathrm{Cs}^{+}$for the capture and disposal of nuclear waste.

As an example, Figure 1 shows the change, with time, of the angle $(\Delta \theta)$ of the PAN control adsorbent in response to the addition of substrate $\mathrm{Cs}^{+}$.

The relationship between the observed shift in the incident angle $(\Delta \theta)$ and the substrate (metal ion) concentration leads to an apparent adsorption isotherm. Figure 2 summarizes the apparent adsorption isotherms of $\mathrm{Cs}^{+}$and $\mathrm{Na}^{+}$for the control PAN and PAN adsorbents molecularly imprinted with $\mathrm{Cs}^{+}$. Figure $2 \mathrm{a}$ reveals that specific recognition sites toward $\mathrm{Cs}^{+}$or $\mathrm{Na}^{+}$were nearly absent in the control PAN adsorbent. Contrary to the control PAN adsorbent, the adsorbents molecularly imprinted with $\mathrm{Cs}^{+}$, such as Cs-025, Cs-050 and Cs-075 (Figures 2b-d), gave dual adsorption isotherms toward $\mathrm{Cs}^{+}$, whereas $\mathrm{Na}^{+}$was incorporated into these adsorbents nonspecifically. Against our expectations, the apparent adsorption isotherm of Cs-100, which had a molecular imprinting ratio of 1.0 (Figure 2e), hardly showed a dual adsorption isotherm toward $\mathrm{Cs}^{+}$. $\mathrm{Na}^{+}$was again adsorbed nonspecifically on Cs-100. The increase in the molecular imprinting ratio might result in an increase in the amount of the print molecule. Those molecules that did not effectively work as a print molecule only resulted in the formation of pores. This shows that the print molecule did not have a substantial effect.

In adsorption studies on enantiomers ${ }^{31,35}$ or on analogues, such as adenosine and guanosine, ${ }^{30,32-34}$ the amount of each substrate adsorbed can be estimated from $\Delta \theta$. Although the absolute value cannot be determined from $\Delta \theta$ in such studies, relative values, such as the adsorption selectivity, can be determined.

In the present study, $\Delta \theta$ for $\mathrm{Cs}^{+}$and $\mathrm{Na}^{+}$cannot be compared because of the very different natures of these two types of alkali metal ions. ${ }^{39}$ However, it is interesting and indispensable to quantitatively determine the adsorption selectivities of the adsorbents in the present study. To this end, adsorption experiments were carried out. Using the concentration of adsorbed $\mathrm{Cs}^{+}$or $\mathrm{Na}^{+}$determined by the adsorption study at $1.0 \times 10^{-2} \mathrm{~mol} \mathrm{dm}^{-3}$ and the results of SPR spectroscopy at

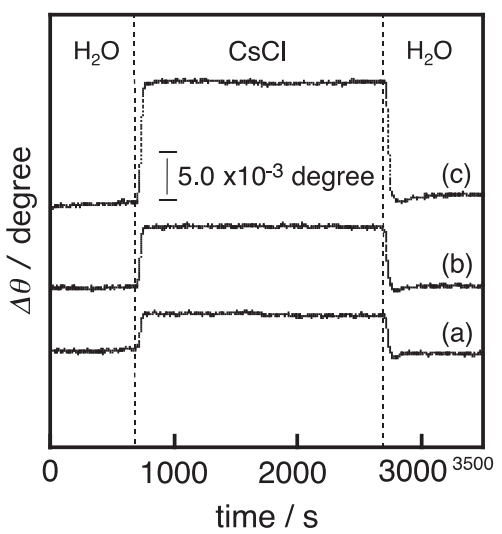

Figure 1 Typical time courses of the angle change $(\Delta \theta)$ of surface plasmon resonance (SPR) in response to the addition of $\mathrm{Cs}^{+}(\mathrm{CSCl})$ from an aqueous solution to the polyacrylonitrile (PAN) control adsorbent. The sensor part was first stabilized in aqueous solution and then flowed through $\mathrm{Cs}^{+}$, and finally washed by an aqueous solution: (a) $[\mathrm{CsCl}]=3.0 \times 10^{-3} \mathrm{~mol} \mathrm{dm}^{-3}$; (b) $[\mathrm{CsCl}]=5.0 \times 10^{-3} \mathrm{~mol} \mathrm{dm}^{-3}$; (c) $[\mathrm{CsCl}]=1.0 \times 10^{-2} \mathrm{~mol} \mathrm{dm}^{-3}$. 
a

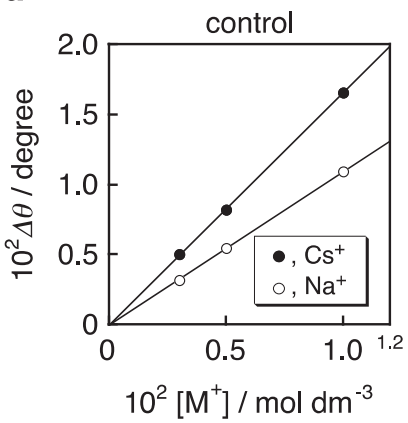

b

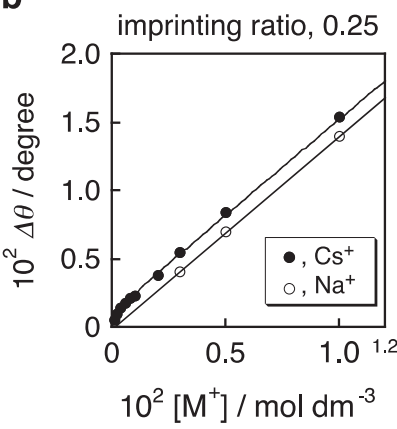

C

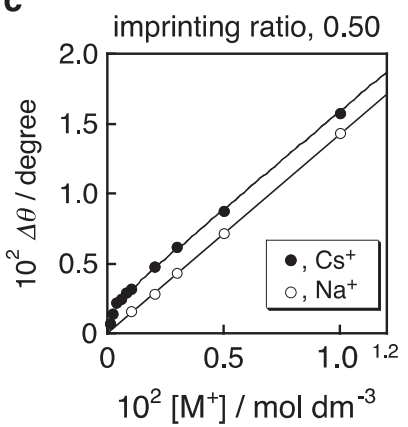

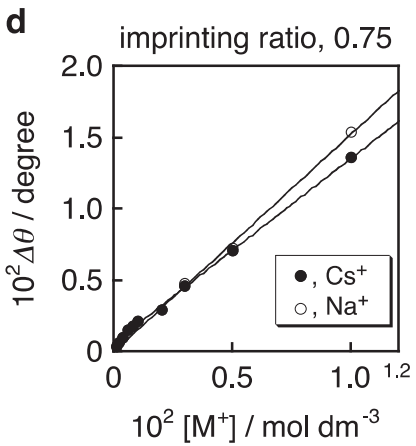

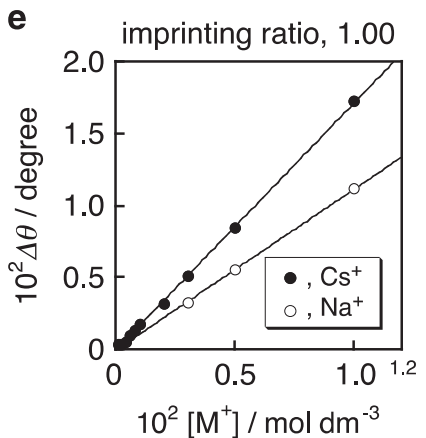

Figure 2 Adsorption isotherms of $\mathrm{Cs}^{+}$and $\mathrm{Na}^{+}$of the control polyacrylonitrile (PAN) adsorbent (a), and PAN adsorbents molecularly imprinted with $\mathrm{Cs}^{+}$, namely, Cs-025 (b), Cs-050 (c), Cs-075 (d) and Cs-100 (e). Adsorption isotherms are given in angle change $(\Delta \theta)$.
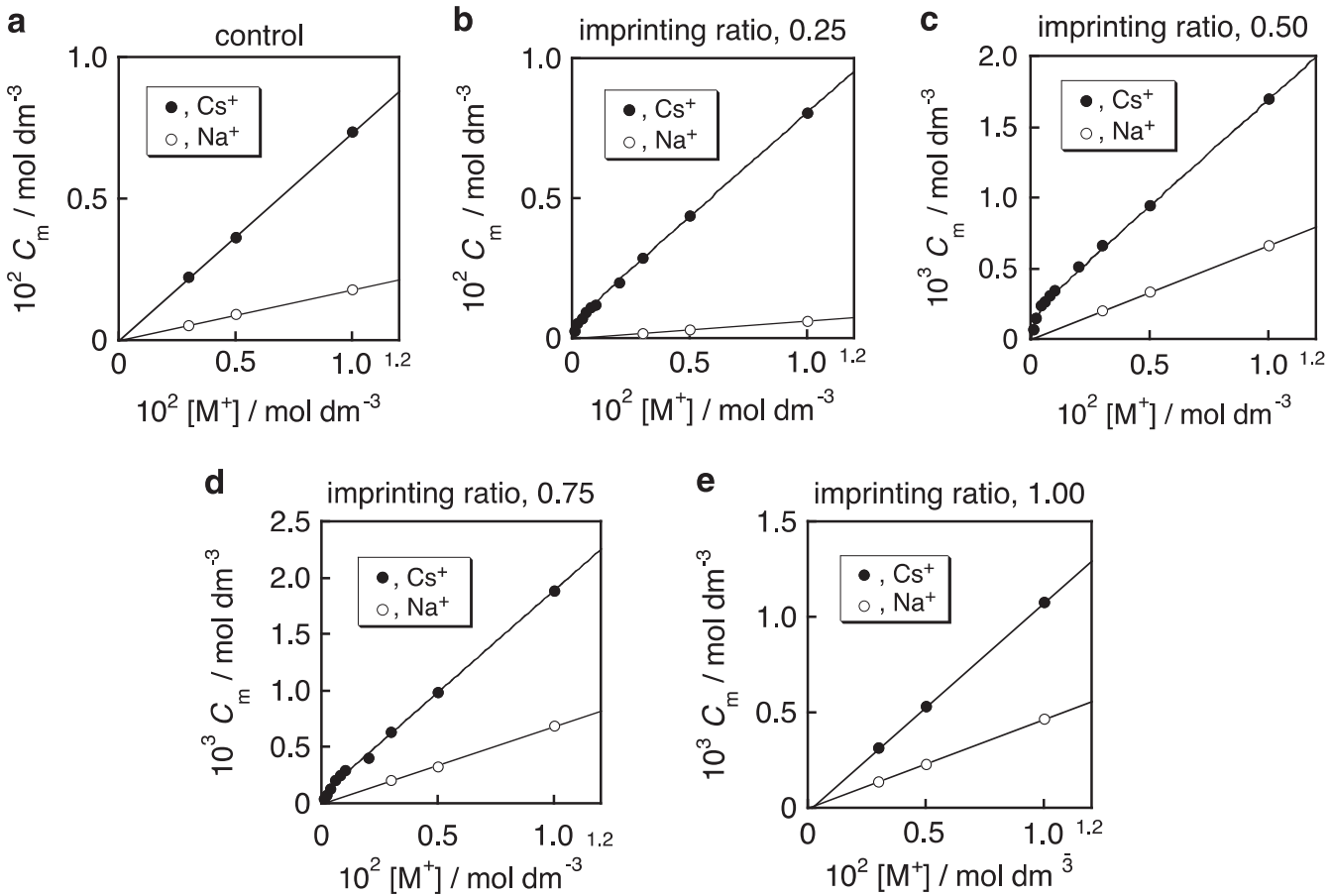

Figure 3 Adsorption isotherms of $\mathrm{Cs}^{+}$and $\mathrm{Na}^{+}$of the control polyacrylonitrile (PAN) adsorbent (a), and PAN adsorbents molecularly imprinted with Cs ${ }^{+}$, namely, Cs-025 (b), Cs-050 (c), Cs-075 (d) and Cs-100 (e). Adsorption isotherms are given in concentration (mol dm ${ }^{-3}$ ).

the same concentration, the apparent adsorption isotherm determined by SPR spectroscopy was converted to the absolute values $\left(\mathrm{mol} \mathrm{dm}{ }^{-3}\right)$. Such converted apparent adsorption isotherms are shown in Figure 3.

The dual adsorption isotherms of $\mathrm{Cs}^{+}$for Cs-025, Cs-050 and Cs-075 display nonspecific and specific adsorption in the
$\mathrm{Cs}^{+}$-recognition sites, which were formed in the presence of the print molecule $\mathrm{Cs}^{+}$during the adsorbent preparation process. ${ }^{30-34}$ The concentration of $\mathrm{Cs}^{+}$in the adsorbent can be represented by the following equation:

$$
\left[\mathrm{Cs}^{+}\right]_{\mathrm{PAN}}=k_{\mathrm{A}, \mathrm{Cs}}\left[\mathrm{Cs}^{+}\right]+K_{\mathrm{S}}[\text { Site }]_{0}\left[\mathrm{Cs}^{+}\right] /\left(1+K_{\mathrm{S}}\left[\mathrm{Cs}^{+}\right]\right)
$$


where $\left[\mathrm{Cs}^{+}\right]_{\text {PAN }}\left(\mathrm{mol} \mathrm{dm}{ }^{-3}\right)$ denotes the concentration of $\mathrm{Cs}^{+}$in the adsorbent, $k_{\mathrm{A}, \mathrm{Cs}}$ is the adsorption constant for nonspecific adsorption, $\left[\mathrm{Cs}^{+}\right]\left(\mathrm{mol} \mathrm{dm}{ }^{-3}\right)$ is the concentration of $\mathrm{Cs}^{+}$in an aqueous solution equilibrated with the PAN adsorbent molecularly imprinted with $\mathrm{Cs}^{+}, K_{\mathrm{S}}\left(\mathrm{mol}^{-1} \mathrm{dm}^{3}\right)$ denotes the affinity constant between $\mathrm{Cs}^{+}$ and $\mathrm{Cs}^{+}$-recognition sites and $[\text {Site }]_{0}\left(\mathrm{~mol} \mathrm{dm}^{-3}\right)$ is the total concentration of $\mathrm{Cs}^{+}$recognition sites in the adsorbent.

The nonspecific adsorption isotherm for the control PAN adsorbent is represented by Equation (2). The adsorption isotherm for Cs-100 can be approximately represented by Equation (2):

$$
\left[\mathrm{M}^{+}\right]_{\mathrm{PAN}}=k_{\mathrm{A}, \mathrm{i}}\left[\mathrm{M}^{+}\right]
$$

where $\left[\mathrm{M}^{+}\right]_{\text {PAN }}\left(\mathrm{mol} \mathrm{dm}^{-3}\right)$ denotes the concentration of metal ions nonspecifically adsorbed on the adsorbent $\left(\mathrm{M}^{+}, \mathrm{Cs}^{+}\right.$or $\left.\mathrm{Na}^{+}\right), k_{\mathrm{A}, \mathrm{i}}$ is the adsorption constant $(\mathrm{i}, \mathrm{Cs}$ or $\mathrm{Na})$ and $\left[\mathrm{M}^{+}\right]\left(\mathrm{mol} \mathrm{dm}^{-3}\right)$ denotes the concentration of $\mathrm{Cs}^{+}$or $\mathrm{Na}^{+}$in aqueous solution equilibrated with the adsorbent.

The parameters in Equations (1) and (2), which were determined from the best fits to each adsorption isotherm in Figure 3, are summarized in Table 2. The adsorption constants for both cesium

Table 2 Parameters for adsorption isotherms

\begin{tabular}{|c|c|c|c|c|c|}
\hline Adsorbent & Control & Cs-025 & Cs-050 & Cs-075 & Cs-100 \\
\hline Imprinting ratio ${ }^{a}$ & 0 & 0.25 & 0.50 & 0.75 & 1.00 \\
\hline$k_{\mathrm{A}, \mathrm{Cs}}$ & 0.74 & 0.74 & 0.15 & 0.18 & 0.11 \\
\hline$K_{\mathrm{S}}\left(\mathrm{mol}^{-1} \mathrm{dm}^{3}\right)$ & - & $4.2 \times 10^{3}$ & $7.1 \times 10^{3}$ & $6.9 \times 10^{3}$ & - \\
\hline$[\text { Site }]_{0}\left(\mathrm{~mol} \mathrm{dm}^{-3}\right)$ & - & $7.1 \times 10^{-4}$ & $2.0 \times 10^{-4}$ & $1.0 \times 10^{-4}$ & - \\
\hline$k_{\mathrm{A}, \mathrm{Na}}$ & 0.18 & 0.063 & 0.066 & 0.068 & 0.047 \\
\hline
\end{tabular}

Abbreviations: $k_{\mathrm{A}, \mathrm{CS}}$, adsorption constant for nonspecific adsorption of $\mathrm{Cs}^{+} ; K_{\mathrm{S}}$, affinity constant between $\mathrm{Cs}^{+}$and $\mathrm{Cs}^{+}$-recognition sites; [Site] $]_{0}$, total concentration of $\mathrm{Cs}^{+}$recognition sites in the adsorbent.PAN, polyacrylonitrile; $k_{\mathrm{A}, \mathrm{Na}}$, adsorption constant for nonspecific adsorption of $\mathrm{Na}^{+}$.

${ }^{a}$ (Mole number of $\left.\mathrm{Cs}^{+}\right) /($mole number of constitutional repeating unit of PAN). and sodium ions were decreased by the presence of $\mathrm{Cs}^{+}$during the adsorbent preparation process, except in the Cs-025 adsorbent. The adsorption constant of $\mathrm{Cs}^{+}$for Cs- 025 was the same as that for the control adsorbent.
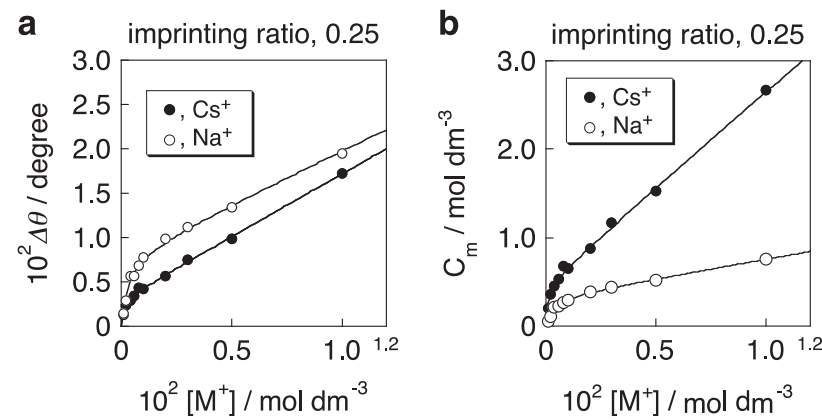

Figure 5 Adsorption isotherms of $\mathrm{Cs}^{+}$and $\mathrm{Na}^{+}$for polyacrylonitrile (PAN) adsorbents molecularly imprinted with $\mathrm{Na}^{+}$, namely, Na-025. Adsorption isotherms are given in angle change $(\Delta \theta)$ (a) and in concentration $(\mathrm{mol} \mathrm{dm}-3)$ (b).

Table 3 Parameters for adsorption isotherms for $\mathrm{Na}^{+}$-imprinted adsorbent $^{\mathrm{a}}$

\begin{tabular}{lcc}
\hline & $\mathrm{Cs}^{+}$ & $\mathrm{Na}^{+}$ \\
\hline$k_{\mathrm{A}, \mathrm{Cs}}$ & $2.2 \times 10^{2}$ & - \\
$K_{\mathrm{S}}\left(\mathrm{mol}^{-1} \mathrm{dm}^{3}\right)$ & $8.3 \times 10^{3}$ & $3.2 \times 10^{3}$ \\
{$[\text { Site }]_{0}\left(\mathrm{~mol} \mathrm{dm}^{-3}\right)$} & $4.8 \times 10^{-1}$ & $3.3 \times 10^{-1}$ \\
$k_{\mathrm{A}, \mathrm{Na}}$ & - & $4.4 \times 10$ \\
\hline
\end{tabular}

Abbreviations: $k_{\mathrm{A}, \mathrm{CS}}$, adsorption constant for nonspecific adsorption of $\mathrm{Cs}^{+} ; K_{\mathrm{S}}$, affinity constant between $\mathrm{Na}^{+}\left(\mathrm{Cs}^{+}\right)$and $\mathrm{Na}^{+}\left(\mathrm{Cs}^{+}\right)$-recognition sites; [Site], total concentration of $\mathrm{Na}^{+}\left(\mathrm{Cs}^{+}\right)$ recognition sites in the adsorbent; $k_{\mathrm{A}, \mathrm{Na}}$, adsorption constant for nonspecific adsorption of $\mathrm{Na}^{+}$. aThe molecular imprinting ratio was fixed to be 0.25 .

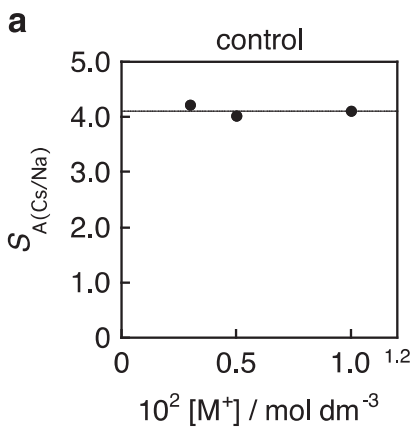

b

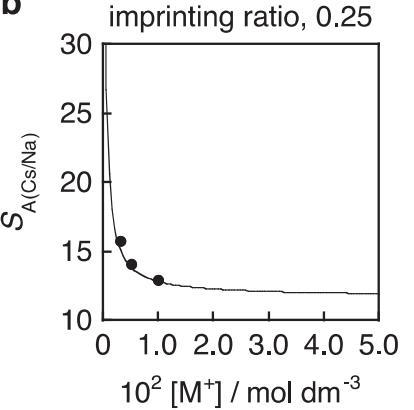

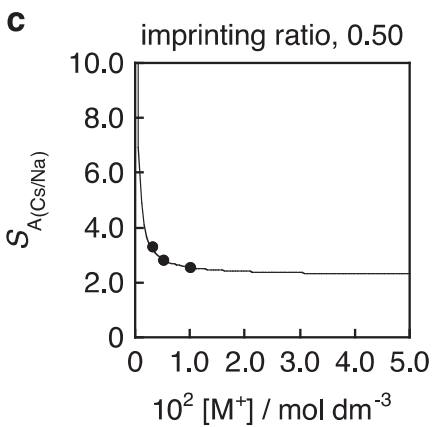
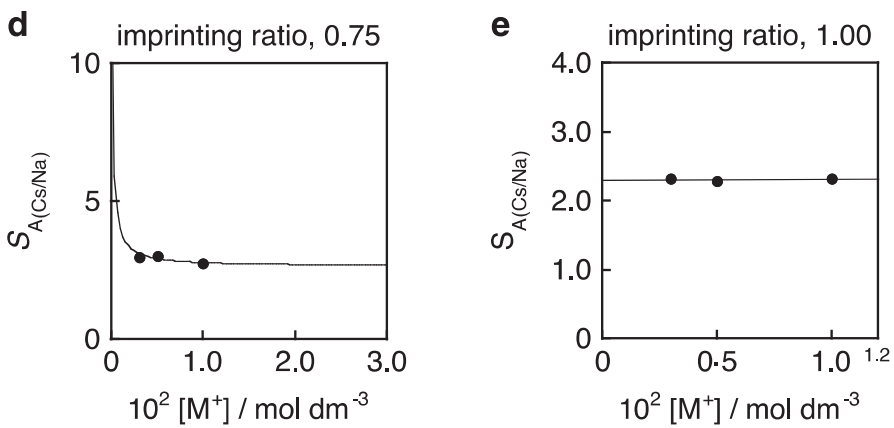

Figure 4 Adsorption selectivity of the control polyacrylonitrile (PAN) adsorbent (a), and PAN adsorbents molecularly imprinted with $\mathrm{Cs}^{+}$, namely, Cs-025 (b), Cs-050 (c), Cs-075 (d) and Cs-100 (e). 
The affinity constant, $K_{S}$, was expected to increase with the decrease in the molecular imprinting ratio, as observed in the recognition of adenosine by modified polysulfone with an oligopeptide derivative of glutamyl residues. ${ }^{30}$ In the present study, however, the maximum affinity constant was observed at the molecular imprinting ratio of 0.50 (Cs-050). This might be explained as follows: the print molecule $\mathrm{Cs}^{+}(\mathrm{CsCl})$ attached to molecular recognition sites located in the central area of the adsorbent was difficult to wash out during the extraction process. This is because some $\mathrm{Cs}^{+}$-recognition sites that were thought to show a high-affinity constant were isolated by long distances in the Cs- 025 adsorbent.

Among the three types of adsorbent, the Cs- 025 adsorbent exhibited the maximum concentration of $\mathrm{Cs}^{+}$-recognition sites, which were formed in the presence of the print molecule $\mathrm{Cs}^{+}$(or $\left.\mathrm{CsCl}\right)$ during the adsorbent preparation process. Generally, the amount of $\mathrm{Cs}^{+}$-recognition sites is thought to increase with the increase in the amount of the print molecule, $\mathrm{Cs}^{+}$, during the adsorbent construction process. However, the increase in the amount of print molecules resulted in the increase in the amount of porogens. This might be because of the decrease in the concentration of $\mathrm{Cs}^{+}$-recognition site with the increase in the molecular imprinting ratio.

The adsorption selectivity toward $\mathrm{Cs}^{+}$against $\mathrm{Na}^{+}$can be determined from the experimental data represented by Equation (3):

$$
S_{\mathrm{A}(\mathrm{Cs} / \mathrm{Na})}=\left(\left(\mathrm{Cs}^{+}\right)_{\mathrm{PAN}} /\left(\mathrm{Na}^{+}\right)_{\mathrm{PAN}}\right) /\left(\left[\mathrm{Cs}^{+}\right] /\left[\mathrm{Na}^{+}\right]\right)
$$

where $\left(\mathrm{Cs}^{+}\right)_{\text {PAN }}$ and $\left(\mathrm{Na}^{+}\right)_{\text {PAN }}$ are the amounts of $\mathrm{Cs}^{+}$and $\mathrm{Na}^{+}$, respectively, incorporated into the adsorbent, and $\left[\mathrm{Cs}^{+}\right]$and $\left[\mathrm{Na}^{+}\right]$ denote the concentrations of $\mathrm{Cs}^{+}$and $\mathrm{Na}^{+}$, respectively, in the solution equilibrated with the adsorbent. In addition to this, the adsorption selectivity $S_{\mathrm{A}(\mathrm{Cs} / \mathrm{Na})}$ can be theoretically calculated by substituting Equations (1) and (2) into Equation (3):

$$
\begin{aligned}
S_{\mathrm{A}(\mathrm{Cs} / \mathrm{Na})}= & \left(k_{\mathrm{A}, \mathrm{Cs}} / k_{\mathrm{A}, \mathrm{Na}}\right)\left(\left[\mathrm{Cs}^{+]} /\left[\mathrm{Na}^{+}\right]\right)\right. \\
& \times\left\{1+K_{\mathrm{S}}[\mathrm{Site}]_{0} /\left(1+K \mathrm{Ks}\left[\mathrm{Cs}^{+}\right]\right)\left(k_{\mathrm{A}, \mathrm{Cs}}\left[\mathrm{Cs}^{+}\right]\right)\right\}
\end{aligned}
$$

The adsorption selectivity at ambient concentrations can be calculated using Equation (4).

The adsorption selectivities for the five types of adsorbent in the case that the adsorbent is in contact with an equimolar mixture are shown in Figure 4. Those determined from experimental results are shown by closed circles while each line is the adsorption selectivity calculated from Equation (4) adopting parameters summarized in Table 2. The adsorption selectivity for the control adsorbent is not dependent on the substrate concentration because both $\mathrm{Cs}^{+}$and $\mathrm{Na}^{+}$ were nonspecifically adsorbed on it. In the case of the Cs-100 adsorbent, the adsorption selectivity is apparently independent of the substrate concentration. The $\mathrm{Cs}^{+}$-imprinted adsorbents, such as Cs-025, Cs-050 and Cs-075, show a dependence on substrate concentration, as anticipated from the dual adsorption isotherm showing that $\mathrm{Cs}^{+}$was incorporated onto the adsorbent. As a result, the adsorption selectivity increases with the decrease in concentration.

\section{Mechanism for construction of $\mathrm{Cs}^{+}$-recognition sites}

It is interesting and indispensable to elucidate the mechanism for the formation of $\mathrm{Cs}^{+}$-recognition sites on the $\mathrm{Cs}^{+}$-imprinted adsorbent. To this end, $\mathrm{Na}^{+}$was used as a print molecule instead of $\mathrm{Cs}^{+}$to prepare a $\mathrm{Na}^{+}$-imprinted adsorbent. In the present study, $\mathrm{NaClO}_{4}$ was adopted as a source for print molecules of $\mathrm{Na}^{+}$because $\mathrm{NaCl}$ is nearly insoluble in both HFIP and DMF. Figure 5a shows the apparent adsorption isotherms of $\mathrm{Cs}^{+}$and $\mathrm{Na}^{+}$, which were determined by following a similar procedure as that described in the previous section.
Contrary to expectations, both $\mathrm{Cs}^{+}$and $\mathrm{Na}^{+}$were incorporated onto the $\mathrm{Na}^{+}$-imprinted adsorbent, following a dual-adsorption mechanism. In a sense, the observed phenomena are natural. The parameters for the dual-adsorption isotherm were determined from the best fit to each adsorption isotherm shown in Figure $5 \mathrm{~b}$ and are summarized in Table 3.

Both $\mathrm{Cs}^{+}$and $\mathrm{Na}^{+}$were adsorbed, following a dual adsorption mechanism even when the adsorbent was constructed in the presence of $\mathrm{Na}^{+}\left(\mathrm{NaClO}_{4}\right)$ as a print molecule. The actual species of the print molecule are solvated metal ions rather than naked metal ions. Accordingly, molecular recognition sites constructed in the presence of $\mathrm{Cs}^{+}$might be smaller than those in the presence of $\mathrm{Na}^{+}$. Although the dimensions of each print molecule in the molecular imprinting process have not been clarified at the moment, the dimensions of $\mathrm{Na}^{+}$ might be larger than those of $\mathrm{Cs}^{+}$, by analogy with the hydrated radii of these metal ions ${ }^{40}$ and the dimensions and solvation numbers for $\mathrm{Li}^{+}, \mathrm{Na}^{+}$and $\mathrm{K}^{+}$in organic solvents. ${ }^{41}$ The hydrated radii of $\mathrm{Na}^{+}$ and $\mathrm{Cs}^{+}$were reported to be $3.58 \times 10^{-10}$ and $3.29 \times 10^{-10} \mathrm{~m}$, respectively. ${ }^{40}$ This supports the results obtained in the present study; $\mathrm{Na}^{+}$was nonspecifically adsorbed on the $\mathrm{Cs}^{+}$-imprinted adsorbent, as shown in Figures 2 and 3. As a result, the hydrated $\mathrm{Cs}^{+}$can be incorporated into the $\mathrm{Na}^{+}$-recognition sites because hydrated $\mathrm{Cs}^{+}$is smaller than hydrated $\mathrm{Na}^{+}$. Furthermore, it is anticipated that solvated $\mathrm{Cs}^{+}$should be smaller than solvated $\mathrm{Na}^{+}$in both HFIP and DMF, which should be addressed in a future study.

The affinity constant for $\mathrm{Cs}^{+}$was determined to be higher compared with that for $\mathrm{Na}^{+}$. From this, it is concluded that the dimensions of $\mathrm{Na}^{+}$-recognition sites provide a better fit for $\mathrm{Cs}^{+}$than $\mathrm{Na}^{+}$. In addition, it is reasonable to expect that the radius of $\mathrm{Na}^{+}$ solvated by DMF might be similar to the hydrated radius of $\mathrm{Cs}^{+}$, which should be clarified with supporting data in a future study. This may also explain why the total concentration of recognition sites for $\mathrm{Cs}^{+}$was determined to be higher compared with those for $\mathrm{Na}^{+}$.

\section{CONCLUSIONS}

Polymeric materials can be directly converted into molecular recognition materials by applying alternative molecular imprinting. This approach can be used to obtain adsorbents for the specific adsorption of cesium ions. To this end, a polymeric adsorbent was converted from PAN, adopting cesium chloride as a print molecule. The adsorption ability of the molecularly imprinted adsorbent was studied by SPR spectroscopy and atomic absorption analysis. The results revealed that $\mathrm{Cs}^{+}$-recognition sites were constructed in the presence of $\mathrm{CsCl}$ during the adsorbent preparation process. The affinity constant between $\mathrm{Cs}^{+}$and $\mathrm{Cs}^{+}$-recognition sites ranged from $4.2 \times 10^{3}$ to $7.1 \times 10^{3} \mathrm{~mol}^{-1} \mathrm{dm}^{3}$. The adsorbents obtained in the present study are expected to be useful for specific adsorption to capture the nuclear waste, $\mathrm{Cs}^{+}$.

1 Kemsley, J., Tremblay, J.-F. \& Johnson, J. Japan fights for its rising sun. C\&EN 89, 8-9 (2011).

2 Faustino, P. J., Yang, Y., Progar, J. J., Brownell, C. R., Sadrieh, N., May, J. C. Leutzinger, E., Place, D. A., Duffy, E. P., Houn, F., Loewke, S. A., Mecozzi, V. J., Ellison, C. D., Khan, M. A., Hussain, A. S. \& Lyon, R. C. Quantitative determination of cesium binding to ferric hexacyanoferrate: Prussian blue. J. Pharm. Biomed. Anal. 47, 114-125 (2008).

3 Kitajima, A., Tanaka, H., Minami, N., Yoshino, K. \& Kawamoto, T. Efficient cesium adsorbent using Prussian blue nanoparticles immobilized on cotton matries. Chem. Lett. 2012, 1473-1474 (2012).

$4 \mathrm{Hu}$, B., Fugetsu, B., Yu, H. \& Abe, Y. Prussian blue caged in spongiform adsorbents using diatomite and carbon nanotubes for elimination of cesium. J. Hazard. Mater. 217-218, 85-91 (2012). 
5 Tammawong, C., Opaprakasit, P., Tangboriboonrat, P. \& Sreearunothai, P. Prussian blue-coated magnetic nanoparticles for removable of cesium from contaminated environment. J. Nanopart. Res. 15, 1689 (2013).

6 Mimura, H. \& Kanno, T. Distribution and fixation of cesium and strontium in zeolite A and chabazite. J. Nucl. Sci. Technol. 22, 284-291 (1985).

7 Lasperas, M., Cambon, H., Brunel, D., Rodriguez, I. \& Geneste, P. Cesium oxide encapsulation in faujasite zeolites effect of framework composition on the nature and basicity of intrazeolitic species. Microporous Mater. 7, 61-72 (1996).

8 Chan, H.-L. \& Shih, W.-H. A general method for the conversion of fly ash into zeolites as ion exchangers for cesium. Ind. Eng. Chem. Res. 37, 71-78 (1998).

9 Borai, E. H., Harjila, R., Malinen, L. \& Paajanen, A. Efficient removal of cesium from low-level radioactive liquid waste using natural and impregnated zeolite minerals. J. Hazard. Mater. 172, 416-422 (2009).

10 Endo, M., Yoshikawa, E., Muramatsu, N., Takizawa, N., Kawai, T., Unuma, H., Sasaki, A., Masano, A., Takeyama, Y. \& Kahara, T. The removal of cesium ion with natural Itaya zeolite and the ion exchange characteristics. J. Chem. Technol. Biotechnol. 88, 1597-1602 (2013).

11 Kobayashi, T., Ohshiro, M., Nakamoto, K. \& Uchida, S. Decontamination of extradiluted radioactive cesium in Fukushima water using zeolite-polymer composite fibers. Ind. Eng. Chem. Res. 55, 6996-7002 (2016).

12 Wulff, G. Molecular imprinting in cross-linked materials with the aid of molecular templates - a way towards artificial antibodies. Angew. Chem. Int. Ed. Engl. 34, 1812-1832 (1995).

13 Molecular and Ionic Recognition with Imprinted Polymers (eds Bartsch R. A. \& Maeda, M.) (ACS, Washington, DC, USA, 1998).

14 Piletsky, S. A., Panasyuk, T. L., Piletskaya, E. V., Nicholls, I. A. \& Ulbricht, M. Receptor and transport propwerties of imprinted polymer membranes-a review. J. Membr. Sci. 157, 263-278 (1999).

15 Haupt, K. \& Mosbach, K. Molecularly imprinted polymers and their use in biomimetic sensors. Chem. Rev. 100, 2495-2504 (2000).

16 Molecularly Imprinted Polymers Man-Made Mimics of Antibodies and their Applications in Analytical Chemistry (ed. Sellergren, B.) (Elsevier, Amsterdam, The Netherlands, 2001).

17 Ulbricht, M. Membrane separation using molecularly imprinted polymers. J. Chromatogr. B 804, 113-125 (2004).

18 Alexander, C., Andersson, H. S., Andersson, L. I., Ansell, R. J., Kirsch, N., Nicholls, I. A., O'Mahony, J. \& Whitcombe, M. J. Molecular imprinting science and technology: a survey of the literature for the years up to and including 2003. J. Mol. Recogn. 19, 106-180 (2006).

19 Maier, N. M. \& Lindner, W. Chiral recognition applications of molecularly imprinted polymers: a critical review. Anal. Bioanal. Chem. 389, 377-397 (2007).

20 Rao, T. P., Kala, R. \& Daniel, S. Metal ion-imprinted polymers-novel materials for selective recognition of inorganics. Anal. Chim. Acta 578, 105-116 (2006).

21 Ewen, S. L. \& Steinke, J. H. G. Molecularly imprinted polymers using anions as templates. Struct. Bond 129, 207-248 (2008).

$22 \mathrm{Wu}, \mathrm{X}$. Molecular imprinting for anion recognition in aqueous media. Microchim. Acta 176, 23-47 (2012).
23 Yoshikawa, M. in Molecularly Imprinted Polymeric Membranes for Optical Resolution in Molecular and Ionic Recognition with Imprinted Polymers (eds Bartsch R. A. \& Maeda, M.) ACS Symposium Series 703, 170-187 (ACS, Washington, DC, USA, 1998).

24 Yoshikawa, M. Molecularly imprinted polymeric membranes. Bioseparation 10, 277-286 (2002).

25 Yoshikawa, M., Higuchi, A. in Enantioselective Membrane in Encyclopedia of Membrane Science and Technology (eds Hoek E. M. V. \& Tarabara, V. V.) (Wiley, New York, NY, USA, 2013).

26 Michaels, A. S., Baffour, R. F., Bixler, H. J. \& Choo, C. Y. Conditioned polyethylene as a permselective membrane. Ind. Eng. Chem. Process Des. Dev. 1, 14-25 (1962).

27 Wulff, G. \& Sarhan, A. The use of polymers with enzyme-analogous structures for the resolution of racemates. Angew. Chem. Int. Ed 11, 341 (1972).

28 Organic Solvents 4th edn (eds Riddick J. A., Bunger W. B. \& Sakano, T. K.) (Wiley, New York, NY, USA, 1986).

29 Kice, J. L. Inhibition of polymerization. I. Methyl methacrylate. J. Am. Chem. Soc. 76, 6274-6280 (1954).

30 Taniwaki, K., Hyakutake, A., Aoki, T., Yoshikawa, M., Guiver, M. D. \& Robertson, G. P. Evaluation of the recognition ability of molecularly imprinted materials by surface plasmon resonance (SPR) spectroscopy. Anal. Chim. Acta 489, 191-198 (2003)

31 Yoshikawa, M., Hotta, N., Kyoumura, J., Osagawa, Y. \& Aoki, T. Chiral recognition sites from carbonyldioxyglyceryl moiety by an alternative molecular imprinting. Sens. Actuator B 104, 282-288 (2005).

32 Yoshikawa, M., Guiver, M. D. \& Robertson, G. P. Molecularly imprinted films from Torlon polyamide-imide. J. Mol. Struct. 739, 41-46 (2005).

33 Yoshikawa, M., Kawamura, K. \& Watanabe, K. Evaluation of the recognition ability of molecularly imprinted proteins by surface plasmon resonance (SPR) spectroscopy. Membrane 32, 49-44 (2007).

34 Yoshikawa, M., Guiver, M. D. \& Robertson, G. P. Surface plasmon resonance studies on molecularly imprinted films. J. Appl. Polym. Sci. 110, 2826-2832 (2008).

35 Nakagawa, M., Ikeuchi, Y. \& Yoshikawa, M. Chiral separation of racemic amino acids with novel polyamides having $N$ - $\alpha$-acetyl-L-glutamyl residue as a diacid component. Polymer 49, 4612-4619 (2008).

36 Yoshikawa, M. \& Izumi, J. Chiral recognition sites converted from tetrapeptide derivatives adopting racemates as print molecule. Macromol. Biosci. 3, 487-498 (2003).

37 Eagen, C. F. \& Weber, W. H. Modulated surface-plasmon resonance for adsorption studies. Phys. Rev. B19, 5068 (1979).

38 Nylander, C., Liedberg, B. \& Lind, T. Gas detection by means of surface plasmon resonance. Sens. Actuators 3, 79-88 (1983).

39 Atkins, P., Overton, T., Rourke, J., Weller, M. \& Armstrong, F. in Shriver and Atkins' Inorganic Chemistry 5th edn (Oxford University Press, Oxford, UK, 2011).

40 Nightingale, E. R. Jr. Phenomenological theory of on solvation. Effective radii of hydrated ions. J. Phys. Chem. 63, 1381-1387 (1959).

41 Conway, B. E., Bockris, J. O'M. in Modern Aspects of Electrochemistry (eds Bockris J. O'M. \& Conway, B. E.) 64 (Butterworth, London, UK, 1954). 